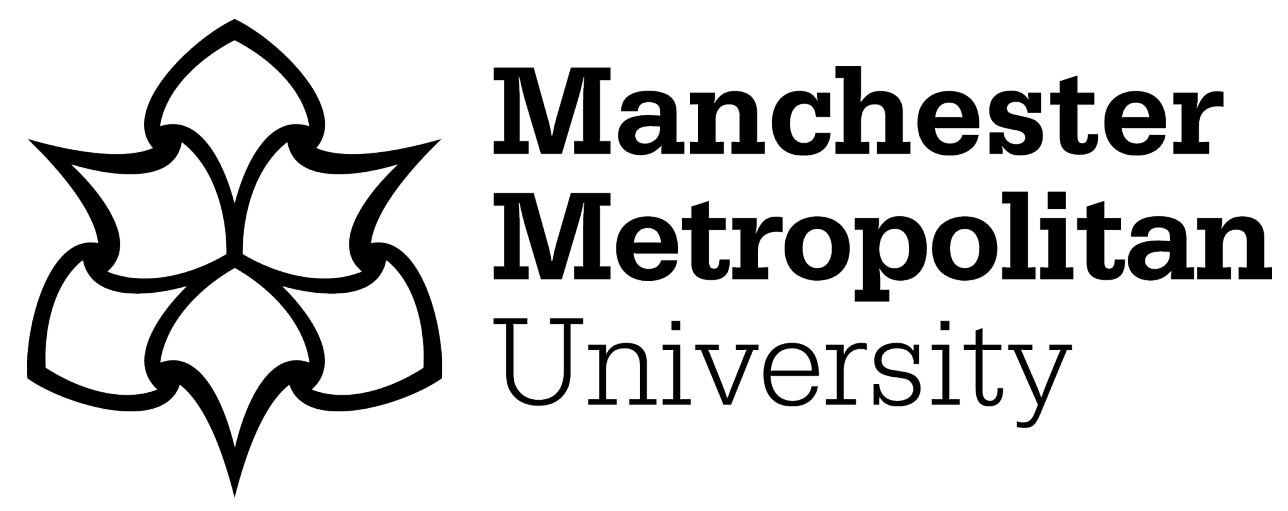

Fenemore, Mark ORCID logoORCID: https://orcid.org/0000-0001-9872-3757 (2020) Victim of kidnapping or an unfortunate defector? The strange case of Otto John. Cold War History, 20 (2). pp. 143-160. ISSN 1468-2745

Downloaded from: https://e-space.mmu.ac.uk/624448/

Version: Accepted Version

Publisher: Taylor \& Francis

DOI: https://doi.org/10.1080/14682745.2019.1689390

Please cite the published version 


\title{
Victim of kidnapping or an unfortunate defector? The strange Case of Otto John
}

\section{Mark Fenemore}

\begin{abstract}
Dr Otto John was a controversial choice as head of the Office for the Protection of the Constitution, West Germany’s domestic counter-espionage agency. After attending a commemoration of the victims of the resistance plot against Hitler, on 20 July 1954, John disappeared from West Berlin in the company of his friend Dr Wolfgang Wohlgemuth. This article explores available evidence from CIA and Stasi files to assess whether John was abducted or went freely as a would-be defector. An examination of his mental state is crucial in determining this. Arguably, this event could have constituted a pivotal event in the cold war, yet the details have hitherto remained cloaked in confusion and mystery.
\end{abstract}

Keywords: espionage, defection, Cold War Berlin, CIA, KGB, Stasi, BfV, German resistance, Adenauer, National Socialism, communism, German unification

Late at night in July 1954, in what might have become a pivotal event in the cold war, a customs guard waved through a car at a border crossing with East Berlin. Unbeknownst to him, it contained the head of West German counter-intelligence. ${ }^{1}$ This was at the height of the Stasi's kidnapping campaign. ${ }^{2}$ Using new and existing evidence, this article tests out the thesis put forward by Bernd Stöver that Otto John crossed the border voluntarily rather than being abducted. ${ }^{3}$ Although highly opaque, the Stasi files do suggest important information about John's mood, psyche and motivations. The article will explore John's biography, his appointment as counter-intelligence chief and his disappearance from West Berlin. It will 
then examine his stay in East Germany and the Soviet Union before his abrupt return to the West.

Unlike many of his countrymen, Otto John had an unblemished record as an opponent of the Nazi dictatorship. From 1937, while working for Germany’s commercial airline (Lufthansa), he had been part of the resistance movement and had participated in preparations for the 20 July 1944 plot against Hitler. His work as a lawyer in Lufthansa's Madrid office enabled him to make contacts with British intelligence. Thanks to his position, he became unofficial foreign minister for the German resistance, pursuing negotiations with the sceptical allies. When he realised that the plot to kill the Führer had failed, he escaped from Berlin to Lisbon. Despite being arrested by the Portuguese and chased by the Gestapo, John managed to make it to Britain. There was nothing he could do to save his brother Hans, who was executed by the Nazis. Engaging himself fully with the British war effort, John worked closely with senior intelligence operative Sefton Delmer at a special propaganda unit.

At Delmer's prompting, during the last months of the war John made propaganda broadcasts on British radio (Soldatensender Calais), calling on German soldiers to give up. While John vociferously defended the resistance as German patriots, this stance put him at odds with many of his fellow countrymen and the postwar German establishment. The most serious unproven accusation was that he treasonably revealed the location of the V-2 rocket testing station in Peenemünde, leading to a bombing raid by the Royal Air Force. What is true is that, after the war was over, John acted as a screener on behalf of British intelligence, deciding which high-ranking officers to release from the Prisoner of War camps. At the time, senior German Generals thought that he was genuine and helpful, even though he made no secret of his contempt for Nazism. He went on to observe the prosecutions at Nuremberg for 
six months in 1946, gathering material for a book. In the minds of those who had supported and defended the Third Reich, this signalled John's transformation from amiable persecutee to vengeful prosecutor. It led them to question his patriotism and loyalty. In 1949, he increased these suspicions by acting as a translator and legal assistant for the prosecution of Field Marshal Erich von Manstein in Hamburg. John's apparent shift from a 'father confessor' welfare role to active legal pursuance went down very badly in military circles; they saw this as an unforgivable betrayal. ${ }^{4}$ For his part, he saw anyone who had failed to support the abortive 20 July plot as an unrepentant Nazi. From now on, John's many domestic opponents tended to see him as effectively 'a German in British battle dress'. Several close friends - even committed anti-Nazis - advised him to stop working for the British. They saw him as, in effect, delivering his fellow countrymen 'to the Allied hangman'. The accusations speak both of John's integrity and value system, but also of his relative isolation in nascent West Germany.

\section{$\underline{\text { An unusual choice as counter-intelligence chief }}$}

After the Federal Republic of Germany was established in May 1949, British advisers put John forward for the job of Director of the Federal Office for the Protection of the Constitution (BfV), the most important domestic intelligence agency in the new state. ${ }^{6}$ Although the cold war was well under way, the British decision to support John's candidature reflected a legacy of allied tutelage. Although they supported Konrad Adenauer's government, they wanted a body to oversee it and, explicitly, to protect the fragile constitution. For their part, the Americans pushed to have former General Reinhard Gehlen appointed instead, viewing John as little more than an isolated and unpopular British spy. ${ }^{7}$ The Western Allies considered and rejected twelve other candidates before they finally 
settled on John. Chancellor Konrad Adenauer had little say in the matter; when the BfV was founded in autumn 1950, he viewed it as an unnecessary appendage. The BfV would operate in the foreground; the real espionage would be carried out by Gehlen's Organization, forerunner of the Federal Intelligence Service (BND).

Not a political animal, John made no secret of his strong beliefs, particularly his disgust at the German establishment's pusillanimity and failure to resist Hitler prior to 1945. John was one of the few Germans who did not need to be ashamed of what they had done in the Third Reich. Nevertheless, the purism that made him irreproachable for the British caused friction with the more opportunistic Gehlen. When he interviewed John in January 1952, the exiled writer Manfred George emphasized his rare political integrity: 'I found Dr John a quiet, sober and determined man... an implacable opponent of Nazism - his innate sense of justice was outraged by what he saw... ${ }^{8}$

John was carefully vetted, but the CIA viewed him as a dubious and unfortunate appointment, and was subsequently critical of what it regarded as his inefficient management. In its view, he lacked even basic counter-espionage experience and had unrealistic expectations. Critics judged him as vain and prone to emotion. For someone with responsibility for rooting out enemy infiltration, he was far too incautious about the people with whom he associated himself. According to CIA author Trimble,

How was it that Otto John, a man who already showed signs of needing watching himself, almost an expatriate, whom Chancellor Adenauer is said to have disliked from first sight, was named head of the sensitive Bundesamt für 
Verfassungsschutz? Or, as the Germans put it in their rough peasant proverb,

'Who put the goat in charge of the garden?'9

John had links with the Minister for All-German Affairs, Jakob Kaiser, together with President Theodor Heuss, but for the CIA it was, above all, British backing that got him the post.

The heavy burdens of counter-intelligence demanded someone who could shoulder them. By mid-1954, four years into the job, John was seen as manifestly unstable, overloaded and under strain; if he ever had been, he was no longer up to the tasks of the job. Numerous critics suggested that John was incapable of fulfilling his functions, was mired in conflict with his superiors and was at considerable risk of being sacked. In the altered circumstances of mid-1950s Germany, his moral obstinacy made him appear aloof and untrustworthy. In the new situation of partially restored sovereignty, he had been upset by the pervasive venom directed at him and his work by regrouping networks of former Nazis. For his part, Gehlen who appeared to have Adenauer's backing as well as that of the Americans - briefed against John, claiming that he was a Soviet as well as a British agent. ${ }^{10}$ Although Gehlen's 'intellectual Heimat' was the Wehrmacht rather than National Socialism, he allowed Nazi networks to infiltrate and work for his organization. ${ }^{11}$ Adding to his difficulties, John lacked experience in administration and had to handle underlings appointed by others. Cases of apparent administrative incompetence began to stack up.

Even his British backers had started to have doubts about his suitability: 'For some little while we have felt that the Germans should do well to replace John. Our doubts on John's suitability were based on his inefficiency and his general attitude towards his work. ${ }^{12}$ As 
well as rumours that he was drinking heavily, in spite of warnings he insisted on maintaining contacts with dubious characters. John reassured the British that he was being careful. The CIA also pointed to an overfondness for alcohol: 'his favourite sport when pixelated being to snap the elastic of women's brassieres.' Nevertheless, enemies also rumoured that he was a double agent and/or a homosexual. ${ }^{13}$

On Tuesday, 20 July 1954, John was in West Berlin for the tenth anniversary of the plot to overthrow Hitler that had cost his brother's life. At the ceremony in the Dahlemer Church, he was visibly moved. Later, at the Bendlerstrasse, he expressed anger and annoyance at two people who appeared to be making fun of the ceremony. The apparent presence of former National Socialists at a commemoration of their victims irked him immeasurably. Trimble was more critical, saying that John made a loud and embarrassing exhibition of himself, visibly sobbing while condemning two other mourners as Gestapo agents. ${ }^{14}$ That evening, tired and emotional, the intelligence chief disappeared from West Berlin. He left his hotel without saying goodbye to his wife, with whom he was on strained terms. He appeared morose, agitated, guarded and uncommunicative. He was in such a funk that those closest to him could not get through to him: he was in an unreachable daze. John was last seen in the company of a 'salon communist' acquaintance called Dr. Wolfgang Wohlgemuth. ${ }^{15}$ Wohlgemuth (routinely pictured holding a champagne glass) was a libertine, trumpetblowing, playboy gynaecologist who worked at the Charité hospital in East Berlin. A roué and a rake, he owned several properties in West Berlin (for use by his 20-year-old wife and mistresses), including a surgery off the Kurfürstendamm. The handsome and debonaire Wohlgemuth was well known for his unreliability, his lack of morals and his 'erotic excesses' (his third wife had started out as a teenage patient). Despite his dubious reputation as a 
smooth-talking Communist sympathizer and pill-pusher, John trusted him because he had treated his brother Hans for serious injuries during the war.

Wohlgemuth had belonged to the Socialist Unity Party (SED) until 1949. He claimed he was trusted by neither side: for the Americans, he was a Communist; for the Soviets, he was pro-American. He was one of those figures caught between the fronts of cold-war Berlin, but seemed to be profiting from his ambivalent position. When the intelligence chief disappeared, the press speculated whether the untrustworthy doctor had blackmailed, drugged or even hypnotised him. Wohlgemuth's wife revealed that he was in the habit of tape-recording his patients and friends. When he subsequently arrived at the nearby Charité, Wohlgemuth is supposed to have said 'I have got mixed up in something stupid. He got me into a real mess. And I've also lost my car. ${ }^{16}$ Wohlgemuth returned briefly to West Berlin to leave a letter expressing concern that he might be accused of having influenced John's decision. He subsequently insisted that John had gone East voluntarily, but his accounts of events were not always consistent. Although Wohlgemuth was clearly untrustworthy, it was not clear why he would give up the girls and the booze, not to mention his rewarding medical practice, to deliver John to the Soviets.

Although kidnapping was a common feature of the 'war of nerves' in Berlin, John was by far the most important and symbolically valuable figure to disappear in the city since the onset of the cold war. It emerged that John had emptied his pockets before leaving the hotel. This suggested that he was careful not to take anything sensitive with him to Wohlgemuth's practice. This led the Times to wonder if he had truly crossed the border with the intention of betraying his country. However, the paper also suggested that he would have been more use to the Soviets as a double agent. ${ }^{17}$ Only a month previously, while on a visit to the USA, John 
had had dinner with Allen Dulles, director of the CIA. Dulles recalled the meeting as irksome and inconsequential. The two men had not clicked, let alone shared confidences. Beyond denying that he was a British agent, John had made little impression on his American counterpart. $^{18}$

Shortly before his disappearance, John had been observed to be in a highly strung and disheartened, dispirited state. He had been passing information about renascent German militarism and Nazism on to his old friend, and former boss, Sefton Delmer for articles in the Daily Express. ${ }^{19}$ As the press scrambled to make sense of his disappearance, intelligence operatives provided dirt and smears. His reputation was thoroughly dragged through the mud. Referring to his history of defecting and to his lack of efficacy, some operatives had nicknamed him boomerang. Based on a statement by his wife, shortly after his disappearance, The Times reported that John had been suffering from acute and hopeless despondency. The intelligence chief had been mentally exhausted, worn down by his work, and deeply moved by the tenth anniversary of the plot. The newspaper quoted John's wife as saying that this despair 'arose from private as well as professional causes. ${ }^{, 20}$

\section{Broadcast from East Berlin}

Two days after his disappearance, official East German sources broke their silence by announcing that John had sought asylum in the GDR. With great fanfare, the Prime Minister's press office announced that the head of the BfV had made contact with the GDR government with the aim of discussing the reunification of Germany. The Stasi seemed to have pulled off a major coup: the head of the West German counter-intelligence organization 
was now in their hands and seemed to be supporting East German propaganda. A statement was issued in John's name:

To my German fellow-citizens, Germany stands in danger of being torn asunder for ever through the dispute between East and West. Some demonstrative action is required in order to call upon all Germans to work for reunification. Therefore on the anniversary of July 20 , I have taken a decisive step and have established contact with the Germans in the East. ${ }^{21}$

John criticized Adenauer's remilitarization policy as particularly damaging to the prospect of reunification. He complained of being continually attacked and ridiculed by Nazis, who were emerging into important positions in West German society as well as in Adenauer's administration. After he went, his opponents gleefully argued that, 'Once a traitor, always a traitor' ${ }^{22}$ Gehlen and his former comrades viewed John's actions in making contact with the British during the war as inexcusable. ${ }^{23}$ John's apparent defection removed a tiresome rival and painted the remaining anti-Nazi resistance figures as Soviet agents. With John gone, there was nothing to stop his meteoric rise; he now had Adenauer's full confidence and the criticisms were discredited.

In a subsequent radio broadcast, this time made by the man himself, John suggested that the fiercely anti-Soviet West German Chancellor was avoiding making a decisive and determined break with the past in the Federal Republic. It is true that Adenauer prized experienced civil servants for their efficiency even if they had served the National Socialist regime. ${ }^{24} \mathrm{He}$ was prepared to ignore their past crimes if they helped build the new state and its economy. In 1949, he had appointed Hans Globke as 'virtual head' of his Federal 
Chancellory. Dr Globke had co-authored one of the Nuremberg Laws, thereby playing a crucial role in formulating Nazi racial policy. ${ }^{25}$ Historians point to a number of prominent exNazis, as well as key former generals, who strongly influenced the fledgling FRG. ${ }^{26}$ Article 131 of the Basic Law allowed the return of soldiers, policemen and civil servants in defiance of denazification. ${ }^{27}$ Personnel audits merely removed the most heinous individuals. ${ }^{28}$ Following the broadcast, Adenauer referred to John's Übergang - 'going over' - but refused to speculate on his motives. The West German Minister of the Interior, Gerhard Schröder, initially offered a reward of 500,000 DM for information on what had happened. Once John spoke out, he was convinced that the exiled intelligence chief would be briefly exploited for propaganda purposes then ultimately cast aside and liquidated. ${ }^{29}$

In his radio address, on 28 July, John elaborated on the dramatic gesture he wanted to make in terms of the prospect of German reunification. Suggesting that 'a resolute step' was necessary, he stated that he had been deprived of an opportunity to discuss his fears of a Nazi and militarist resurgence in the Federal Republic. The political climate of West Germany made a similar statement impossible there. So instead, he had made contact with the East Germans. A public warning was not enough; action was necessary to change Germany's fate. Historian and former intelligence operative, Hugh Trevor-Roper, stresses how the emotional atmosphere of the anniversary of the plot against Hitler could have heightened this sense of betrayal. ${ }^{30}$ In John's mind, Adenauer's divisive, American-backed pursuit of remilitarization was inextricably linked to the revival of National Socialism and the threat of a new war. The only way to ensure that war did not occur and that Germany could be reunited was for a dramatic reconciliation between East and West. In this respect, John's views overlapped with those of the Soviets. 
The BfV chief's apparent defection put the cat among the pigeons and had tragic consequences for some of his associates. Ten days after John's disappearance, his friend Wolfgang Hoefer, whom he had known since school, committed suicide. This unleashed another wave of press reports. ${ }^{31}$ Like his friend, the BfV chief, Hoefer was depressed and fed up with espionage work. Bitterly disillusioned, he wanted nothing more to do with the secretservice racket. John said that Hoefer had revealed to him that he had been tasked by the Americans with spying on him.

Despite John's public statements about a Nazi resurgence, the mystery surrounding his sudden disappearance remained. Speculation continued about whether John had been abducted or blackmailed into defecting. Nevertheless, when he appeared at a press conference on 11 August 1954, the former intelligence chief appeared happy and relaxed. Unlike Cardinal Mindszenty, who had appeared dazed and confused during his 1949 trial, nothing about John's demeanour suggested that he was acting against his will. He basked in the attention of the world's media and stayed on message, even when he was temporarily out of earshot of his Soviet minders. Accusing Adenauer of recycling former Nazis and militarists, he claimed to have taken up his office because he hoped to assist in the construction of a new Germany, purged of National Socialism. ${ }^{32}$ For American journalists, Dr John looked alert and in full control of his faculties. Showing no signs of duress or ill-treatment, he was completely at ease in making his condemnation of Adenauer's policy. Whatever the circumstances of his arrival in the GDR, it was clear that his fears about Nazism were genuine and unfeigned. Those who witnessed his performance stated that he spoke with conviction and sincerity. After fielding questions, John came down into the audience, shaking hands with old friends and acquaintances. Although they dismissed his claims as the result of sinister Pavlovian brainwashing, CIA commentators were perturbed. The normally taciturn Dulles was shocked 
by how closely he stuck to the Soviet propaganda line. ${ }^{33}$ Having carefully coached their pawn, the Soviets had scored a major victory. Adenauer called John's apparent defection petrifying. Interior Minister Schröder saw it as a major setback in the cold war, causing a crisis of confidence in the young Bundesrepublik.

After this highly public emotional highpoint, John disappeared once again. It later turned out that he had been whisked off to Moscow and to the Black Sea coast for three months of intensive questioning. It was telling that John referred to this in a letter to his wife as a 'cure'. ${ }^{34}$ In the West, intelligence experts feared that he was revealing the names of agents. Nevertheless, no agents appeared to have been lost because of information provided by John. ${ }^{35}$

\section{Life in the golden cage}

Surviving Stasi files draw a veil over how John came to be in East Berlin in the first place, but they do reveal certain aspects of his life as a guest of the GDR state. After his curative sojourn in the USSR, John was taken back to East Germany. In his discussions with the Stasi, John said that he wanted to take part in public life in the GDR and to use his newfound celebrity to try to influence the population of East and West Germany in favour of reunification. The British communist publishers, Lawrence \& Wishart, wrote to him, inviting him to write a short book on the situation in Germany. They were eager to publish his views on the problem of German re-armament and the resurrection of Nazism. At such a fraught geopolitical juncture, 'such a book' promised to have a big impact in Britain. ${ }^{36}$ Once he was in East Berlin, John cooperated fully with the orchestrated GDR press campaign and spoke several times on East German radio. Having been responsible for combating the dictatorial 
East German regime, in public he now expressed his wholehearted support for it. He fulfilled his obligations to his East German hosts with numerous press conferences in the provinces. He even met with the eighty-year-old writer, Thomas Mann, in Weimar.

For his safety and protection, the Stasi lodged John with a family of its employees: mother, father, daughter, son-in-law and John all lived together in a secluded cottage in Schmöckwitz. The house was relatively luxurious by East German standards: it was secluded, down a narrow private lane, and had access to a lake (the Zeuthener See) and two gardens. In the summer, he was allowed to use two motorboats. To provide additional protection, they suggested getting a guard dog. John was provided with an office in the Committee for German Unity. Built-in microphones recorded everything he said whether at home, at work or in the car. The Stasi justified their mistrust on the grounds that they wanted to avoid people negatively influencing him or trying to kidnap him back to the West. They tried to limit his contacts to those associated with the 20 July plot and a few, handpicked, reliable GDR citizens. His handlers were to drive him around, but never to let him out of their sight. If John had publically expressed his distrust of Adenauer's decision-making, the Stasi showed little faith in their convert, feelings he reciprocated.

Very quickly, John fell out of the limelight and into another deep depression. Embarking on an alternative approach to Adenauer and to West Germany, the Soviets lost interest in their increasingly troublesome guest. The campaign for a neutral, united Germany seemed to have run its course. John wrote to his wife that he was reduced to acting as an 'itinerant preacher for reunification'. ${ }^{37}$ The Stasi allowed John's friends and family contact. Some of his visitors were taken in by the apparent luxury, not seeing the constraints. With little to do in his golden cage and surrounded by people who constantly monitored his actions, John 
again began to drink heavily. He led his Stasi handlers on a merry dance, often starting drinking at lunchtime and going on wild pub crawls. The Stasi noted alcoholism as his chief characteristic. ${ }^{38}$ When drunk, he drew attention to himself with loud and vociferous arguments in public. Instead of being an asset to East German intelligence, John increasingly became something of an embarrassment. After one particularly intense drinking session, he told a Belgian companion, 'Say hello to the old Nazis over there'. His friend replied 'You mean the Nazis who are here'. 39

If John had genuinely defected, his attempts to shake up German politics and to put unification back on the agenda appeared to have failed. It was just the same-old denunciations and counter-fulminations. In 1954 as in 1944, his attempt to alter history had resulted in anti-climax and disillusionment. He gave up his attempt to write a book and now mostly just read newspapers in his office. ${ }^{40}$ In his letters to associates, he expressed feelings of isolation, seclusion and despondency. His Stasi minders linked his dejection to the apparent impossibility of rapidly bringing about reunification. Their suggestions for him to 'have patience - because the timing was not yet right - did not seem to make any impression on him. ${ }^{, 41}$ With Khrushchev prepared to recognize West Germany, the Soviets no longer needed John. People in the West, whose opinion he trusted, kept asking him why he had not stayed in West Germany to gather support for his position. If he was so keen on democratic renewal, why had he not raised the matter with the Western press? As Interior Minister Schröder perceptively noted: 'His whole character and sympathies were with the west and all his friends and relations were there. ${ }^{42}$ His meaning-sustaining network and support base both lay on the other side of the border. In a letter to a fellow resister, Fritz Heine of the Social Democratic Party, John argued that the July plotters would have supported his gesture of working with the Communists in order to ensure the denazification of Germany. ${ }^{43}$ 
Nevertheless, even if he had truly believed this, he seemed less and less convinced. His correspondence revealed that public opinion in Western Europe had failed to swing behind him. Rather than functioning as a catalyst, he was dismissed as a traitor and a self-defeating crank.

Isolated and in despair, he was lonely and he missed his wife; she did not trust the Communists enough to come over. While John was driving his motorboats and downing cocktails, she had been forced out of their official residence. When the BfV stopped paying John's salary, she had no choice but to sell most of their furniture to keep the family going. Swedish criminologist Harry Söderman wrote to John and asked him why he had decided to leave 'this poor, dear woman in such a cruel way'. John's wife could not believe that he had gone over voluntarily: 'She sticks to the theory that you were hypnotized.' ${ }^{44}$ Suggesting that John might have been temporarily insane, he nevertheless defended the former counterintelligence chief against claims that he was a drinker or a homosexual. ${ }^{45}$

While his wife was forced to take cover from the press by returning to England, John grew increasingly dispirited and melancholic. If he had gone over voluntarily, the feeling of having betrayed his country for no real gain must have weighed heavily on him. The propaganda impact and potency had ebbed away; he was just another minor news story. Calling his prison a monkey's cage, John complained of all the people listening in around him. John, the antiNazi resistance fighter, who had given up everything to combat the former Nazis, got into the habit of punctuating his comments with Heil Hitler and raising his arm in public in a Nazi salute. His Stasi handlers rated him as 'really impudent, imperious and demanding' ${ }^{46}$ The childish, public singing of American hit songs underlined his helplessness and lack of fit with 
his surroundings. Nevertheless, Ernst Wollweber's underling, Erich Mielke, was apparently planning a film of John's life, in part to keep him distracted. ${ }^{47}$

Stasi chief Wollweber met with him personally to try and persuade him to sober up. He could not convince John that he had taken the right course of action in coming over to East Berlin. Nevertheless, he tried to convince the man who had once been his opposite number to draw a line under the past and to build himself a new life in the East. ${ }^{48}$ Even in his cups, John said nothing to Wollweber about having been kidnapped. Although he now deeply regretted his choice, everything in his 24-volume Stasi file suggests that it had been his choice to come over. Even at his most unguarded and candid, he continued to insist that he had come freely: 'Do you know why I came over to the GDR? Because I could not stand it anymore. ${ }^{49}$ This suggested that unhappiness with West German conditions had led to his rash action. Everything points to an abrupt and injudicious rather than a carefully considered move. The Stasi consistently spoke of John's defection or crossing over to the GDR rather than of a kidnap or an arrest. ${ }^{50}$ They referred to discussions with John rather than to interrogations.

\section{'Boomerang' returns}

On 12 December 1955 his handlers drove John to a meeting at the Humboldt University on Unter den Linden. He left them and his briefcase in the car, saying that he would only be half an hour. 'Because he frequently left us waiting... four or five hours past the time he had stated, it did not unduly worry us when he did not [immediately] reappear. ${ }^{51}$ In reality, he went straight through the building and out to a street at the back where the journalist Hendrik Bonde-Henriksen was waiting for him. John ducked into the car, a green Ford with Danish 
number plates. The Dane took him through the Brandenburg Gate disguised with glasses, a hat and scarf and a pipe. As they crossed the border,

Otto John was deeply moved and the tears rolled down his cheeks. How wonderful that this nightmare is over, he said with a hoarse voice, and continued: 'I could not have endured it any more. If we had been caught I only had one chance, namely to commit suicide. ${ }^{52}$

The daring escape took only seven minutes, supposedly under the watchful eyes of carefully positioned Allied snipers. It had been planned and coordinated by Danish military intelligence, with the knowledge of the West German authorities. His dramatic and perilous bolt for freedom had an epic quality. A shaky John could not enjoy his freedom long before he was encouraged to leave for West Germany. Once there, he was taken into custody and put on trial. ${ }^{53}$ His strange stay in East Germany had lasted seventeen months. Adenauer is supposed to have burst out laughing when he heard that John had come back. The SPD greeted his return by saying that he was a case for the psychiatrists. ${ }^{54}$

The mystery of how and why John left West Berlin in the first place remained. Journalists asked if he had been motivated by a rash decision (while psychologically vulnerable) or by his political naivety. John claimed that his friend Dr. Wohlgemuth had slipped something into his tea. The version he gave Western intelligence agencies was that he lost consciousness in Wohlgemuth's surgery and woke up in Karlshorst. He confirmed that it was the Soviets who had handled his reception and then had him taken away to Moscow, for three and a half months of intensive questioning (from 25 August to 7 December 1954). 
When they confronted each other years later in court, Wohlgemuth said, 'However miserable our meeting may be to-day, I can only say that you ought not to have drunk so much. ${ }^{55}$ The presence of the two men (John and Wohlgemuth) in court was dramatic and tense, but not particularly illuminating. The more calm Wohlgemuth was, the more angry John got. An unbowed and unrepentant John now maintained that throughout his stay in East Berlin and the Soviet Union, he had acted under duress. He had played along in order to leave the option of escape open. Nevertheless, the British, Americans and West Germans were convinced that he had gone to the eastern sector of his own volition.

At his trial for treason, the case hinged on whether John had defected to the East or been taken there against his will.

In one of his last letters John said that for a long time he had become alienated from his office and wanted to change his profession, but his decision to go over to the East came over him suddenly. After the press conference... John stated that he had not at first intended to remain in the East. ${ }^{56}$

Unavailable at his trial, the Stasi files shed some light on the case. Some of the photographs showed him looking haunted and wary, with bags under his eyes, but others showed him smiling and laughing. ${ }^{57}$ Recalling his time in the Soviet Union, John said that the Soviets 'questioned me nearly to death'. He claimed not to have betrayed any secrets. ${ }^{58}$ This is not entirely true; although he initially refused to give names of agents, under the pressure of continuous, repeated questioning, John provided more and more nuggets of information. The unrelenting questioning wore him down. When the Stasi asked him about the Gehlen Organisation, for example, John gave some names of people involved and details of 
American financing. He also named people who were suspected of being double agents for the Soviets. ${ }^{59}$ In his defence, John said that he had feared being injected with a truth serum. Already weak and vulnerable, he claimed that he had only followed the Soviet propaganda line to avoid being sent to the Soviet Union. There, he was so desperate that he had tried to make himself a noose. However, the available Stasi files - partially reconstructing Soviet interrogations - suggest that over time he became more loose lipped. Towards the end, he was revealing agents' names, ages, place of residence, appearance and occupations. He even revealed which covert operatives could be tempted or blackmailed into cooperation. ${ }^{60}$

Stöver suggests that John may have ceased to be aware of the seriousness of the secrets he was revealing. It is also unclear from the documents whether John really did express himself as the documents record. ${ }^{61}$ In his memoirs, John suggested that the KGB knew more about the BfV than he did. Those who have seen the KGB's summary notes suggest that John provided the Soviets with extensive written reports. These detailed not just the structure, tasks and working methods but also the personnel of the BfV. This contradicts John's claim that he only gave unimportant information. Nevertheless, Murphy and Kondrashev argue that he probably did not give the KGB any information that they did not already know. ${ }^{62}$

During his trial, the extent of John's revelations to the KGB was assumed but not verifiable. British officials referred to the case of Cardinal Mindszenty as evidence of the psychological pressures and manipulation the Soviets could bring to bear. ${ }^{63}$ John took this line when he returned. He said that he only went along with the Soviets and their East German allies because this line of no resistance was what was expected of him and his agents should they fall into enemy hands. He stated that full cooperation was the pre-arranged strategy for BfV personnel in the event of capture. ${ }^{64} \mathrm{He}$ said that if he had refused to 
cooperate then the Soviets would have brainwashed him and forced him to divulge state secrets of real importance. Fears of menticide or drug- or hypnosis-induced mind control were palpable during this period of the cold war. ${ }^{65}$

Although there are still several known unknowns, the evidence suggests that John went over the border voluntarily, but was subsequently kept there against his will. This was the view presented by Vitali Tschernjawski, head of the KGB in Karlshorst in the 1950s, after the fall of Communism. ${ }^{66}$ John said that he deliberately gave the impression of cooperating with the eastern authorities, and their version, in order to keep open his options for taking flight. Nevertheless, until his death in March 1997, the ex-renegade persisted in arguing for his innocence. He would not have crossed the border without having been drugged. However his cooperation at an international press conference so soon - within a month of his arrival reduced credence for the argument that he had been abducted. His willingness to say what the Soviets wanted suggested that he had crossed the border of his own free will.

At his trial, the prosecutor, Dr Max Güde (who had been a member of the NSDAP), described John as a weakling rather than a criminal. Witnesses pointed to his mental immaturity and 'puerility'; they viewed him as not up to the pressures of public service. ${ }^{67}$ If the cold warriors were supposed to form an impenetrable ideological bulwark, made up of a strong interlinked chain of individuals fighting against alien ideals, John had clearly failed. There is a similarity between the way he was presented and the smearing of modern whistleblowers. The court thought that, under the influence of alcohol, he might have taken a rash decision. The suggestion that Wohlgemuth probably took advantage of a moment of weakness or anger at his employers was not out of the question. ${ }^{68}$ The court found John not guilty of treason but convicted him of 'treacherous falsifications' (making claims that would 
have been secret if true). ${ }^{69}$ Arguing that he had crossed over voluntarily, the Court believed that John did not originally want to stay in the East. He had misjudged the situation and had expected to make contacts in the East and then to be able to return.

John did not accept the verdict and spent the rest of his days trying to overturn it. $\mathrm{He}$ believed that the judgement was an attempt by the former Nazi judiciary to smear and punish him for having been part of the resistance. Nevertheless, with insufficient new evidence, his many attempts to reopen the verdict failed. Although some new material emerged, John was essentially a victim of the cold war, distrusted and rejected by both adversaries. Neither side had any further interest in exploring his motivations or providing exculpatory corroboration for his story. When his long-dreamed-of hope of Germany being reunited was finally realised, an 80-year-old Otto John again tried to get his case reopened. Most of his argument was based on statements by a KGB defector and some other Eastern European espionage figures. ${ }^{70}$ However, the Soviet/Russian authorities would not allow his legal team access to the relevant KGB documents. Dr. Wohlgemuth was no longer alive to repeat his version of events. In the event, John's conviction was upheld in December 1995. He tried to appeal the decision, but died in March 1997, still in many respects a discredited and ruined man. Asked by the court to provide evidence, the Federal Commissioner for the Records of the State Security Service (BStU) stated that there was no evidence that John had been brought over the border by force. There again, there is the tiny hint of a suggestion that Wohlgemuth had dealt directly with the Soviets. 'Clearly the preparatory talks took place with Soviet security forces. $^{\text {71 }}$

Despite all the published and unpublished evidence - including the twenty four volumes of Stasi files - how John came to end up in East Berlin remains a mystery. An assessment of his 
state of mind is crucial in assessing whether he was a victim of abduction or a traitor. A Liberal parliamentary representative, Reinhold Maier, suggested that he might have been 'partially abducted, partially led astray'. ${ }^{72}$ According to this view, the Soviets exploited his psychological weakness and disillusionment, but also applied drugs and duress. No conclusive proof, one way or the other, has surfaced. We are limited to partial, second-hand extracts of the contents of KGB files on John. Although the successor to the KGB refused to allow John access to his file, they did offer it for sale to West German journalists working on a documentary about the case. Although arguing that John had come to East Berlin of his own volition 'for a prearranged meeting', they nevertheless suggested that he was a 'dissolute and vacillating man'. ${ }^{73}$ They wanted an agent while he wanted an open break with Adenauer. The KGB file suggested that John initiated and carried out the broadcast on his own and could have left the GDR whenever he wanted to. ${ }^{74}$

These leaked extracts of the Soviet dossier stressed that John's arrival in the Soviet Sector was voluntary and that John was driven by a desire to meet with diplomatic representatives of the USSR to discuss his political views. This was the version that the KGB presented after John published his memoirs in $1969 .{ }^{75}$ The KGB had hoped to recruit him, but John's particular stance - condemning Adenauer but refusing to betray his organization's agents made his recruitment 'inexpedient and unrealistic'. ${ }^{76}$ Kondrashev and Murphy conclude that the KGB viewed John as too emotional and volatile. Undercover agents require equanimity and John lacked this essential quality. ${ }^{77}$ Clutching at straws, John later concluded that the KGB must have abducted him in order to find out how much he (and by extension the British) knew about their mole Kim Philby. Nevertheless, while presenting the Soviet version, Kondrashev and Murphy conclude that we cannot say with certainty whether John went voluntarily to his 'KGB tryst' or whether he was given a helping hand by 
Wohlgemuth. ${ }^{78}$ The latter's comment to his Stasi handlers, 'But I helped you' is interesting if not conclusive. ${ }^{79}$

John was adamant that he crossed the border unconscious and woke up in Karlshorst. A KGB officer suggested that John had been drugged shortly after he arrived in East Berlin in order to soften him up so that he went along with the defection story. Espionage chief Jewgenij Pitowranow stated that when John refused to cooperate by returning to his post as a double agent, they put him to sleep. ${ }^{80}$ This is quite close to John's own version. John argued that he only woke up groggily on the $22^{\text {nd }}$ or $23^{\text {rd }}$ July. Coming out of his stupor, he immediately condemned the 'gangster methods' and practised passive resistance. ${ }^{81}$ Nevertheless, he began to realize that his survival depended on his feigned cooperation: 'I had to say something. I had to play along with them.' He feared that they would use drugs or other means 'to get everything I knew out of me. ${ }^{82}$ Whatever the truth, John clung to the claim that he had been drugged and kidnapped. The precise details of how he came to be on the wrong side of the border remain murky, but this was the version that he maintained and clung to until his death. To stick to the same version for over forty years is quite a performance. $^{83}$

\section{Conclusion}

CIA psychiatrist Alfred Paumier argued that 'probing the wellsprings of John's defection and redefection is necessary' so that we can 'learn to detect betrayal before it is unsheathed' ${ }^{84}$ Churchill's epigram for Russia under Stalin - 'a riddle wrapped in a mystery inside an enigma' - could well apply to John. In December 1971, he referred to the accusations of treachery by writing, 'I dare to say that I have always remained true to myself. ${ }^{85}$ In the 
media frenzy that followed his disappearance, all his faults and foibles were exposed to the world. Nevertheless, he remained opaque and inscrutable. The BfV president was either the Soviets' most high-profile abductee, cowed into cooperation, or a naïve and unstable German patriot, who wore his heart on his sleeve. Although partial and in large parts contradictory, the evidence points to the latter position. John was both an upright and purposeful patriot and a weak and unbalanced person. The ease with which he slipped into the role of critic of Gehlen and Adenauer suggest that these were his sincerely held beliefs.

Trevor-Roper observed, 'To cross the lines once in a time of ideological war is common enough, indeed part of the necessary lubrication of the secret service industry. To cross them twice looks like carelessness. To do so three times suggests a serious problem. ${ }^{96}$ With retrospect, John is seen as a triple agent, caught between the fronts with muddled, tangled loyalties. Stöver suggests that John's actions could be explained by recognizing that how he saw the world was strongly influenced by his experiences in the anti-Hitler opposition. Contacting the KGB was a repeat of his position as secret negotiator for the resistance plotters. Because going over to the enemy was the way he had acted in the past, he could not see another way to accomplish his mission. ${ }^{87}$ What for others would be an impossible leap in the dark was, for him, almost an automatic reaction.

Harry Söderman stated: He [John] was a very sensitive person. The commemoration service for the victims of the 20 July plot, his brother being one of them, really got him down. His flight was madness, but I think John really believed that through his arrival in East Berlin he could promote the reunification of Germany. John's thoughts were still caught up in his wartime experience in the anti-Nazi resistance and his dreams of a new Germany. ${ }^{88}$ 
In Neues Deutschland, John had been quoted as saying that 'a demonstrative act was needed' if all Germans were to commit themselves to denazification and reunification. ${ }^{89} \mathrm{He}$ seems to have been bold or naïve enough to think that his defection could provide the necessary spark for sweeping political reform followed by national unity. CIA writer Delmege Trimble diagnosed him as having a 'persecution and Messiah complex' ${ }^{90}$ Fellow CIA writers Murphy and Bailey talks of John's 'emotional, quixotic nature'. 91

A psychiatric assessment judged him overly in need of admiration and with a tendency to overestimate his own abilities. ${ }^{92} \mathrm{John}$ seems to have genuinely believed that he was guarantor of the values of the German resistance and thereby embodied the integrity of the nation. Witness Dr Hans Egidi, Security Director of the Ministry of the Interior, said that John was driven by romanticism to make dramatic gestures. ${ }^{93}$ John's crossing seems less like ice-cold betrayal and more a hot-headed moment of passion. He does seem to have been highly idealistic and emotionally short-fused, with a tendency to tilt at windmills. ${ }^{94}$ Journalist Don Cook suggested that there was something about his reflective, introspective personality that wired his brain differently to other people. Because 'he had lived dangerously and emotionally', he was conditioned to feel deeply about political issues and to act decisively. ${ }^{95}$ This gave him a taste for melodrama and histrionics.

Distrusting the old military men and opposing the remilitarization that allowed them to reestablish themselves, he was horrified by the prospect of another war and determined to make a stand against it. With hindsight, it seems that John had indelibly fused his pursuit of denazification with a sensational and decisive, sudden gesture. The electrifying act of tying his colours to the mast was both a demonstration of his integrity and an act of betrayal. His 
repeated changing of sides suggested someone prone to adventurous, but impractical and unrealistic actions. He repeatedly felt that going over to the enemy could transform political circumstances and thereby end an intolerable situation. Mentally, he narrowed down his options until only an abrupt volte-face was possible. Rather than a turning point in the cold war, it became a personal tragedy. His letters repeatedly asked his wife to understand his 'sudden' decision. He had personal demons that he sought to slay by demonstratively and repeatedly changing sides. In his determination to alter the political landscape in a radical and unalterable fashion, he became a stuck record or a faulty mechanism. However, the loss of touch with his friends and family (and other support bases) led only to a deeper sense of despair.

John's three apparent defections illustrated his difficulties in finding a political home for his idiosyncratic version of German patriotism. John betrayed his employers, the Adenauer government, out of the conviction that a more noble, united and anti-Nazi Germany was possible. ${ }^{96}$ Despite some initial consternation, his abrupt defection and dereliction of duty failed to galvanize opposition to the remilitarization of West Germany; it did not bring reunification any closer. The apparent betrayal by so important a counter-intelligence figure was a boon to the GDR, as they were still recovering from the June 1953 Uprising. Only J. Edgar Hoover going over to the Communist enemy would have created more cataclysmic a shock. As an insider, John was blowing the whistle on the apparent return of Nazis to the West German government (and its secret service). He revealed how deeply entwined Germany's espionage networks were with the CIA. While a major setback for Adenauer, the disappearance of his rival immeasurably strengthened Reinhard Gehlen's hand. Insulated from the nitty gritty of intelligence work in his own organization, let alone Gehlen's, John could do little damage to West German espionage. 
John's preoccupation was reunification not undermining or destroying the Federal Republic. Exploiting French fears of German military resurgence would have been more effective, if he had stayed at his post and leaked. Nevertheless, the support of such an important symbolic figure - the defender and protector of the West German Constitution no less - helped to establish the GDR propaganda line of clear links between Adenauer's government and a Nazi resurgence. John scuppered his own career by seeking to act as the conscience of the nation. Although his support for the 20 July resistance was noble and brave, henceforth his name was forever associated with treachery and self-destructive failure. The brief period of reckless abandon followed by endless regret and despair would fit with bipolar disorder. It was his misfortune to enter a brief phase of impulsivity or suggestibility at the height of cold-war bipolarity.

This was one of the most enigmatic sagas of the cold war. It revealed a lot about the ambivalence of West German democratic renewal while pointing to the clear hazards of trying to work with the Soviets. The political damage John caused was greater than his impact on espionage activities. Nevertheless, the chief harm was done to the whistleblower himself. Mired in doubt and despair, the boomerang martyred himself with self-inflicted wounds. However he ended up in Karlshorst, John's public statements about resurgent Nazism reflected his sincerely held beliefs. His brief stay in the limelight demonstrated both the problems of West German restoration under Adenauer - with former militarists and Nazis taking over important roles - and the problems of East German Communism - rigid, controlling and with similarities to the Nazi police state. John was both courageous and reckless, clever but ingenuous, a fierce anti-Nazi reduced to making Nazi gestures. However uncomfortable he was in West Germany, he found life in the GDR no easier. His dramatic border crossings, his defection and escape highlighted Berlin's role as world capital of 
espionage and kidnapping. The exact details of what happened still seem illusive. Only John and Wohlgemuth knew what really happened. The article points to the intersection of espionage and mental health. Its contribution is to provide a psychogramm of a presumed traitor.

\footnotetext{
${ }^{1}$ Rudolf Diels, Der Fall Otto John. Hintergründe und Lehren (Göttingen: Göttinger Verlagsanstalt, 1954). Diels had been an early head of the Gestapo. Cf. Gérald Gohier, L'espion aux scrupules (Paris: Gallimard, 1958). Willi Frischauer, The Man Who Came Back. The Story of Otto John (London: Frederick Muller, 1958). Otto John, Zweimal kam ich heim. Vom Verschwörer zum Schützer der Verfassung (Düsseldorf, Vienna: Econ, 1969). ${ }^{2}$ Arthur L. Smith, Kidnap City. Cold War Berlin (Westport: Greenwood Press, 2002). Susanne Muhle, Auftrag: Menschenraub. Entführungen von Westberlinern und Bundesbürgern durch das Ministerium für
} Staatssicherheit der DDR (Göttingen: Vandenhoeck \& Ruprecht, 2015).

${ }^{3}$ Bernd Stöver, "Der Fall Otto John. Neue Dokumente zu den Aussagen des deutschen Geheimdienstchefs gegenüber MfS und KGB”, Vierteljahrshefte für Zeitgeschichte 47:1 (Jan., 1999), 103-136. Cf. Erik Gieseking, Der Fall Otto John: Entführung oder freiwilliger Übertritt in die DDR? (Lauf an der Pegnitz: EuropaforumVerlag, 2005). Although containing new material, notably John's papers at the Imperial War Museum, Hett and Wala generally support Stöver's argument that John crossed the border voluntarily. Benjamin Carter Hett and Michael Wala, Otto John: Patriot oder Verräter. Eine deutsche Biographie (Hamburg: Rowohlt, 2019), 338.

${ }^{4}$ Otto John, Twice Through the Lines: The Autobiography of Otto John, translated by Richard Barry (London: Macmillan 1972), 188.

${ }^{5}$ Delmege Trimble, “The Defections of Dr. John”, [CIA] Studies in Intelligence 4:4 (Fall, 1960): 1-26.

${ }^{6}$ Reinhard Schiffers, Verfassungsschutz und parlamentarische Kontrolle in der Bundesrepublik Deutschland, 1949-1957. Mit einer Dokumentation zum "Fall John" im Bundestagsausschuss zum Schutz der Verfassung (Düsseldorf: Droste, 1997). Constantin Goschler and Michael Wala, 'Keine neue Gestapo': Das Bundesamt für Verfassungsschutz und die NS-Vergangenheit (Reinbek bei Hamburg: Rowohlt, 2015).

\footnotetext{
${ }^{7}$ Bernd Stöver, "Ein Widerstandskämpfer als Verfassungsschutzchef" in Konspiration als Beruf. Deutsche Geheimdienstchefs im Kalten Krieg, ed. Dieter Krüger and Armin Wagner (Berlin: Ch. Links, 2003), 160-178.
} 
${ }^{8}$ Manfred George, “Chief of Bonn's Secret Service. An Interview with Dr. Otto John in Cologne”, New York Herald Tribune, 17 January 1952.

${ }^{9}$ Trimble, "The Defections of Dr. John".

${ }^{10}$ Klaus-Dietmar Henke, Geheime Dienste: Die Politische Inlandsspionage der Organisation Gehlen 1946-1953 (Berlin: Ch. Links, 2018), 433-457, 447. Hett and Wala, Otto John, $123 \mathrm{f}$.

${ }^{11}$ Rolf-Dieter Müller, Reinhard Gehlen, Geheimdienstchef im Hintergrund der Bonner Republik: Die Biographie (Berlin: Ch. Links, 2017), vol. two, 1319-20, 1324, 1327. Gerhard Sälter, “Kameraden. NaziNetzwerke und die Rekrutierung hauptamtlicher Mitarbeiter" in Die Geschichte der Organisation Gehlen und des BND 1945-1968, Jost Dülffer et al. eds (Marburg: Unabhängige Historikerkommission, 2014), 41-52.

12 “From Bonn to Foreign Office”, 23 July 1954, UK National Archives, FO 371/109323.

${ }^{13}$ Trimble, "The Defections of Dr. John".

${ }^{14}$ Ibid.

${ }^{15}$ Over 800 people were interviewed as witnesses, having seen John in the previous days.

16 “Dr. John gab eine 'Erklärung”, Berliner Morgenpost, 24 July 1954.

17 “Dr. John 'Lured’ to East Berlin”, Times, 27 July 1954.

${ }^{18}$ Allen W. Dulles, "Memorandum”, 6 December 1954. The full CIA file on John has not been released.

${ }^{19}$ Sefton Delmer, "Nazis Plot for Power”, Daily Express, 24 July 1954.

20 "Bonn Official Missing. Believed to be in East Zone. Abduction Feared", The Times (23.7.1954).

${ }^{21}$ Federal Commissioner for Stasi Records (BStU), MfS AP 11263/56, Band 16, 90. Cf. "Text of the Statement alleged to have been made by Otto John" (24.7.1954), UK National Archives, FO 371/109323.

${ }^{22}$ Hugh Trevor-Roper, The Secret World: Behind the Curtain of British Intelligence in World War II and the Cold War (London: I.B. Tauris, 2014), 195.

${ }^{23}$ Otto John, “A ‘Traitor’ Speaks”, New York Times, 15 December 1971. For his part, John argued that Gehlen’s actions in handing over all his files to the Americans at the end of the war hardly fulfilled the moral precepts of the Wehrmacht.

${ }^{24}$ Norbert Frei, Adenauer's Germany and the Nazi Past: The Politics of Amnesty and Integration (New York: Columbia University Press, 2002). 
${ }^{25}$ Curt Garner, "Public Service Personnel in West Germany in the 1950s: Controversial Policy Decisions and their effects on Social Composition, Gender Structure, and the Role of Former Nazis", Journal of Social History 29:1 (Autumn, 1995): 25-80, 27, 33-34.

${ }^{26}$ Stöver, "Der Fall Otto John”, 112. Cf. Hett and Wala, Otto John, 253-4.

${ }^{27}$ Bundesgesetzblatt, 13 May 1951.

${ }^{28}$ Christian Mentel and Niels Weise, Die zentralen deutschen Behörden und der Nationalsozialismus. Stand und Perspektiven der Forschung (Potsdam: Zentrum für Zeithistorische Forschung, 2016).

29 “Dr. John 'Lured' to East Berlin”.

${ }^{30}$ Hugh Trevor-Roper, "Why Otto John defected thrice”, Spectator, 11 April 1997, 14-15, 15.

31 “Secret U.S. Spy War on Britain. Dr John tells why agent killed himself”, Daily Worker, 31 July 1954.

32 "Verbatim translation of John's statement August 11" (1954), UK National Archives, FO 371/109323.

${ }^{33}$ CIA, Memorandum for the Director, 12 August 1954.

${ }^{34}$ Hett and Wala, Otto John, 232.

${ }^{35}$ This is contrary to the report, "Vague d'arrestations occidentaux en zone soviétique à la suite de la disparition d'Otto John", Le Monde, 24 July 1954.

${ }^{36}$ BStU MfS AP 11263/56, Band 2, 26.

37 Trimble, "The Defections of Dr. John”.

38 “Auskunftsbericht Dr. Otto John” (Berlin, den 3.11.1955), BStU MfS AP 11263/56, Band 4, $6 f$.

${ }^{39}$ Observation Report, 6 July 1955, BStU MfS AP 11263/56, Band 3, 9.

${ }^{40}$ A forty-seven page book in German was published. Otto John, Ich wählte Deutschland (East Berlin: Ausschuss für Deutsche Einheit, 1954).

41 “Gedanken zum Fall John”, no date, BStU, MfS AP 11263/56, Band 12, 10.

42 “Dr. John 'Lured' to East Berlin”.

${ }^{43}$ As cited by Stöver, “Der Fall Otto John”, 110.

${ }^{44}$ Harry Söderman to Otto John (13.8.1954), BStU, MfS AP 11263/56, Band 1, 188.

45 “Revolver-Harry zum Fall John. 'Flucht war Irrsinn””, BZ, 7 October 1954.

46 “Auskunftsbericht Dr. Otto John”.

${ }^{47}$ Letters from Mielke to Ulbricht, 18 November 1955 and 13 December 1955, BStU as cited by Keith R. Allen, Interrogation Nation: Refugees and Spies in Cold War Germany (Lanham: Rowman \& Littlefield, 2017 ), 82. 
${ }^{48}$ Report (20.7.1955), BStU MfS AP 11263/56, Band 3, $15 f$.

49 “Bericht über die Zusammenkunft 'Keller’ mit der M.” (Berlin, den 2.2.1955), BStU MfS AP 11263/56, Band $2,128 \mathrm{f}$.

${ }^{50} \mathrm{BStU}$ MfS AP 11263/56, Band 23, 2.

51 “Bericht: Begleitung Johns am 12.12.1955” (Berlin, den 14.12.1955), BStU MfS AP 11263/56, Band 4, 77f.

52 "So entwich Otto John seinen Beobachtern in Berlins Ostzone" [translation of an article by Henrik BondeHenriksen]. BStU MfS AP 11263/56, Band 9, 219.

${ }^{53}$ Hochverrat und Staatsgefährdung, vol. 2 (Karlsruhe: C. F. Müller, 1958), 77-156.

54 “SPD: 'Ein Fall für Psychiater’ Bonn kommentiert John-Rückkehr. Adenauer: Nachricht löst Heiterkeit aus”, Spandauer Volksblatt, 14 December 1955.

55 “Dr John drugged or drunk?”, Manchester Guardian (12.12.1958).

56 "Precis of report by the Federal Ministry of Justice on the present state of investigations in the John case issued by the Press Office, Bonn”, 15 September 1954, UK National Archives, FO 371/109323.

${ }^{57}$ See for example Neue Deutsche Wochenschau 257, 31 December 1954. Many of these photographs were designed for propaganda purposes. Others were more personal and private.

58 "So entwich Otto John seinen Beobachtern in Berlins Ostzone".

59 “Eidesstattliche Erklärung” [no date]; “Aussprache“ (27.7.1954), BStU MfS AP 11263/56, Band 1, 13, 24.

${ }^{60}$ Stöver, "Der Fall Otto John”, 114-15.

${ }^{61}$ Ibid., 116, 121.

${ }^{62}$ David E. Murphy, Sergei A. Kondrashev \& George Bailey, Battleground Berlin: CIA vs. KGB in the Cold War (New Haven: Yale University Press, 1997), 195.

63 “From Bonn to Foreign Office”, 27 July 1954, UK National Archives, FO 371/109323. For a full elaboration of the Mindszenty case, see Susan L. Carruthers, Cold War Captives. Imprisonment, Escape and Brainwashing (Berkeley, Los Angeles, London: University of California Press, 2009), $136 \mathrm{f}$.

64 “Direktor des Verfassungsschutzamtes entlastet. Das Verhalten des Angeklagten im Ostsektor hat den vereinbarten Spielregeln entsprochen", Der Kurier, 16 November 1956.

${ }^{65}$ Dominic Streatfeild, Brainwash: The Secret History of Mind Control (London: Hodder \& Stoughton, 2006).

66 “Entführt oder verführt?”, Der Spiegel, 20 September 1993. 
${ }^{67}$ On Dr Güde's membership of the NSDAP, see "Vorführung empfiehlt sich Bonn. Generalbundesanwalt", Der Spiegel, 11 July 1962.

${ }^{68}$ Judgement of 22 December 1956 against Otto John, Landesarchiv Berlin, B Rep 058 vorl. $152801 \mathrm{~h}$.

${ }^{69}$ In particular, John's references to secret clauses in the European Defence Community negotiations, governing allied access to defectors, were diplomatically damaging. Allen, Interrogation Nation, 83.

${ }^{70}$ The former KGB officer most willing to reveal 'secrets' about the John case was in financial difficulties and had a wife who required round-the-clock medical care. He gave several, conflicting accounts of what he knew. Murphy et al, Battleground Berlin, 196.

71 “"Vorermittlungen wegen vermutlicher Verbringung von Dr. Otto John, geb. 10.03.1909, 1954 nach

Ostberlin”, Landesarchiv Berlin, B Rep 058 vorl. 152801h.

72 "Entführt oder verführt?"

${ }^{73}$ CIA: "Intelligence in Recent Public Literature" (ca. 1972), 1-2. CIA Online Library.

${ }^{74}$ Murphy et al, Battleground Berlin, 196, 198.

${ }^{75}$ Hans Frederick, Das Ende einer Legende. Die abenteuerlichen Erlebnisse des Towaritsch Alexander Busch (Munich: Politisches Archiv, 1971).

${ }^{76}$ Report by Pitovranov transmitted via secure telephone to KGB Chairman Ivan Aleksandrovich Serov. SVRA file 76863, vol. 1, p. 68 as cited by Murphy et al, Battleground Berlin, 191.

${ }^{77}$ Murphy et al, Battleground Berlin, 192.

${ }^{78}$ Ibid., 193.

${ }^{79}$ Gieseking, Der Fall Otto John, 408.

80 "Entführt oder verführt?"

${ }^{81}$ John, Zweimal kam ich heim, 259, 274f.

82 “Untruths Dr John Told Russians. Clash with Judges", Manchester Guardian, 20 April 1956. Although no truth serum has been proven, both sides in the cold war were searching for one. John Marks, The Search for the Manchurian Candidate. The Story of the CIA's Secret Efforts to Control Human Behaviour (London: Allen Lane, 1979).

${ }^{83}$ Hett and Wala, Otto John, 335, 338.

${ }^{84}$ Alfred Paumier, “Inside Darkest John”, Studies in Intelligence 5:2 (Spring, 1961), 45-50.

${ }^{85}$ John, “A 'Traitor' Speaks”. 
${ }^{86}$ Trevor-Roper, "Why Otto John defected thrice", 14.

${ }^{87}$ Stöver, "Der Fall Otto John", 120.

88 “Johns Flucht war 'Wahnsinn””, Spandauer Volksblatt, 7 October 1954.

89 “Erklärung des Präsidenten des Bundesamtes für Verfassungsschutz’, Neues Deutschland, 24 July 1954.

${ }^{90}$ Trimble, "The Defections of Dr. John".

${ }^{91}$ Murphy et al, Battleground Berlin, 183.

92 "Entführt oder verführt?"

${ }^{93}$ Stöver, “Der Fall Otto John', 119.

${ }^{94}$ Sylvia Conradt and Kirsten Heckmann-Janz, Der Fall Otto John: Don Quijote im Kalten Krieg (Munich: Der Hör-Verlag, 1999).

${ }^{95}$ Don Cook, “West Allies Approved Appointment of John”, Herald Tribune, 23 July 1954.

${ }^{96}$ Hett and Wala suggest that West Germany did ultimately shift closer to John's position. Hett and Wala, Otto John, 339 . 